Sheffield Hallam University

Centre for Regional Economic and Social Research

\title{
The Impact on Scotland of the new Welfare Reforms
}

\section{Christina Beatty and Steve Fothergill}




\title{
THE IMPACT ON SCOTLAND OF THE NEW WELFARE REFORMS
}

\author{
Christina Beatty and Steve Fothergill \\ Centre for Regional Economic and Social Research \\ Sheffield Hallam University
}

October 2016

DOI: 10.3351/cresr.2017.8449573656

A report to the Social Security Committee of the Scottish Parliament 


\section{Key points}

- Since the 2015 general election, the Westminster Government has initiated a further round of welfare reform. The new figures in this report shows that by 2020-21 Scottish claimants can expect to lose just over $£ 1 b n$ a year as a result of the post-2015 reforms.

- The biggest financial losses can be expected to arise from the four-year freeze in most working-age benefits (£300m a year) and from reductions in work allowances within Universal Credit (£250m). The on-going changeover from Disability Living Allowance to Personal Independence Payments (£190m) and reductions in Tax Credits (£140m) also result in large losses.

- The new, lower Benefit Cap will also affect far more households in Scotland - an estimated 11,000 compared to just 900 hit by the existing cap.

- The new benefit changes come on top of the welfare reforms implemented between 2010 and 2015. These have already resulted in the loss to Scottish claimants of around $£ 1.1 \mathrm{bn}$ a year - somewhat less than first forecast mainly due to the difficulty of bringing down spending on incapacity benefits (these days Employment and Support Allowance).

- There are big variations in the anticipated financial losses across Scotland, with Glasgow City experiencing the largest losses in absolute terms and on a per capita basis. Other older industrial areas across Scotland are also hit hard.

- As a general rule, the more deprived the local authority, the greater the per capita financial 'hit'.

- The anticipated financial loss in Scotland - by 2020-21 an average of £300 a year per adult of working age - is broadly in line with the GB average. In part this is because Scotland is exempt from the new 'Pay to Stay' arrangements for social housing tenants.

- Parallel changes in tax allowances, the minimum wage, and childcare may go some way to offsetting the financial losses for some claimants but it is questionable whether the welfare reforms themselves will result in higher employment or increases in earnings.

- The devolution of welfare powers should not obscure the continuing and dominant role that the UK Government plays in determining welfare spending in Scotland. 


\section{THE IMPACT ON SCOTLAND OF THE NEW WELFARE REFORMS}

\section{Scope and purpose of the report}

The devolution to Scotland of new responsibilities for social security should not obscure the fact that control over the majority of welfare spending in Scotland remains with Westminster. And since the general election in May 2015, the UK government has announced a further major round of welfare reform. This adds to the already substantial reforms introduced between 2010 and 2015 .

The purpose of this report is to document the anticipated impact of these new reforms on Scotland. The focus is on how many people will be affected and on how much money will be lost by claimants. The report also documents how the impact of the new reforms is likely to vary between local authorities.

The new welfare reforms that impact on Scotland apply equally to all other parts of Britain but the impact is not necessarily the same because claimants are concentrated more in some places than others. The financial losses in a particular city or town can be more sometimes much more - than the UK average. It is important to understand just how much Scotland as a whole and each of its constituent authorities can expect to lose.

In a report to the Parliament's Welfare Reform Committee in $2013^{1}$, we documented the financial losses expected in Scotland as a result of the reforms implemented since 2010. In follow-up reports we looked at the expected impact at ward level ${ }^{2}$, on different types of household ${ }^{3}$, and explored the effects on the Scottish labour market ${ }^{4}$. These reports all drew on a unique UK-wide databank on the welfare reforms developed at Sheffield Hallam University.

In looking at the impact of the new reforms the present report is essentially a parallel to the original 2013 report. Our initial estimates of the impacts of the post-2015 reforms across the

\footnotetext{
${ }^{1}$ C Beatty and S Fothergill (2013) The Impact of Welfare Reform on Scotland, Scottish Parliament, Edinburgh

${ }^{2}$ C Beatty and S Fothergill (2014) The Local Impact of Welfare Reform, Scottish Parliament, Edinburgh

${ }^{3}$ C Beatty and S Fothergill (2015) The Cumulative Impact of Welfare Reform on Households in Scotland, Scottish Parliament, Edinburgh

${ }^{4}$ C Beatty, S Fothergill and D Houston (2015) The Impact of Welfare Reform on the Scottish Labour Market, Scottish Parliament, Edinburgh
} 
UK were published in a March 2016 report $^{5}$ and subsequently received coverage in the Scottish press. However, later the same month, in Budget 2016, the Treasury published revised estimates of the financial savings it expects to make as a result of the new reforms. All the figures in the present report have been revised to take the Treasury's new figures into account so the estimates here are all new and up-to-date.

A 'health warning' is nevertheless appropriate. Estimating the impacts of welfare reform is an imprecise science. This is partly because the course of the economy is uncertain (this affects claimant numbers), partly because claimants' behaviour may change in response to the reforms, and sometimes because the available data is less than perfect. The Treasury itself revised down its expectations of the financial savings arising from the post-2015 reforms by more than $£ 0.5 \mathrm{bn}$ a year between the 2015 Summer Budget and Autumn Statement and the 2016 Budget.

All the figures for Scotland presented here take the Treasury's expected financial savings as the starting point. These UK-wide savings are then allocated to local areas principally on the basis of official statistics on claimant numbers and benefit spending in each area. Full details of the methods applying to each of the new reforms are set out in the appendix. The methods applying to the pre-2015 reforms are set out in our 2013 report to the Scottish Parliament ${ }^{6}$.

\section{The pre-2015 reforms: the outturn}

It is appropriate to begin by looking back at the impacts on Scotland of the pre-2015 welfare reforms because these help set the context for the new round of reforms. The 2010-15 Coalition government in Westminster implemented eight main reforms that led to financial losses for claimants in Scotland:

\section{Housing Benefit - Local Housing Allowance}

Changes to the rules governing assistance with the cost of housing for low-income households in the private rented sector. The new rules apply to rent levels, 'excess' payments, property size, age limits for sole occupancy and indexation for inflation.

\section{Non-dependant deductions \\ Increases in the deductions from Housing Benefit, Council Tax Support and other income-based benefits to reflect the contribution that non-dependant household members are expected to make towards the household's housing costs}

\section{Benefit cap}

New ceiling on total payments per household, applying to the sum of a wide range of benefits for working age claimants

\footnotetext{
${ }^{5}$ C Beatty and S Fothergill (2016) The Uneven Impact of Welfare Reform: the financial losses to places and people, CRESR, Sheffield Hallam University

${ }^{6}$ C Beatty and S Fothergill (2013) op. cit.
} 


\section{Personal Independence Payments}

Replacement of Disability Living Allowance by PIP for working age claimants, including more stringent and frequent medical tests, as the basis for financial support to help offset the additional costs faced by individuals with disabilities

\section{Employment and Support Allowance}

Replacement of Incapacity Benefit and related benefits by ESA, with more stringent medical tests, greater conditionality and time-limiting of non-means tested entitlement for claimants in the Work-Related Activity Group

\section{Child Benefit}

Three-year freeze, and withdrawal of benefit from households including a higher earner

\section{Tax Credits}

Reductions in payment rates and eligibility for Child Tax Credit and Working Tax Credit, paid to lower and middle income households

\section{1 per cent up-rating}

Limit in annual up-rating of value of most working age benefits

The majority of these welfare reforms were initiated by the Coalition government in Westminster but the introduction of ESA was a Labour measure that pre-dated 2010 and only took full effect later, whereas the time-limiting of non-means tested ESA entitlement was a Coalition innovation. By March 2016 nearly all the pre-2015 reforms had come into full effect. The important exception is the changeover from DLA to PIP, which is not expected to be completed until March $2018^{7}$.

It is important to note that the Westminster Government also introduced two other reforms that in the event did not impact on claimants in Scotland. One of these was the new Housing Benefit rules on under-occupation in the social rented sector, popularly known as the bedroom tax. In Scotland, the impact on claimants has been averted in full by the Scottish Government's deployment of Discretionary Housing Payments. The other reform averted from claimants was a reduction in Council Tax Support arising from the 10 per cent cut in Westminster Government funding. This reduction was absorbed within Scottish Government and local authority budgets. In Scotland, the financial impact of these two welfare reforms - the bedroom tax and Council Tax Support - therefore fell on public sector budgets rather than benefit claimants.

Additionally, the 2010-15 Coalition government began the introduction of Universal Credit. This is arguably the most ambitious reform of all because Universal Credit is set to replace nearly all means-tested benefits for working-age claimants. However, the introduction of Universal Credit differs from the other reforms considered here because, in its original form at least, it was not intended to reduce overall welfare payments but rather to introduce a standardised withdrawal rate. If Universal Credit reduced the overall benefit bill it would be by 'making work pay' in all circumstances. In practice, the introduction of Universal Credit

\footnotetext{
${ }^{7}$ HM Treasury, Budget 2013
} 
has been long delayed and because of more recent decisions its introduction will now be associated with net reductions in entitlement. These reductions are included in the figures we present for the post-2015 reforms.

The list above of pre-2015 welfare reforms also omits the impact of benefit sanctions. What needs to be remembered here is that the power to impose sanctions is not new - it has been a feature of the benefit system since its inception. What happened after 2010 is that sanctions were more widely applied, especially to those claiming Jobseeker's Allowance, though the numbers and the rate do now appear to have peaked ${ }^{8}$. The financial savings to the Treasury, though not negligible, are likely to be smaller than those arising from all but the most modest of the welfare reforms covered here ${ }^{9}$.

Table 1 compares the initial estimate of the financial loss to claimants in Scotland arising from the pre-2015 welfare reforms, from our 2013 report $^{10}$, with the revised estimate published in $2015^{11}$ and the new estimated outturn by March 2016. There are significant divergences.

Table 1: Estimated financial loss to claimants in Scotland from pre-2015 welfare reforms

\begin{tabular}{|c|c|c|c|}
\hline & $\begin{array}{l}\text { Initial estimate } \\
\text { (2013) } \\
\text { Em p.a. }\end{array}$ & $\begin{array}{c}\text { Revised estimate } \\
\text { (2015) } \\
\text { Em p.a. }\end{array}$ & $\begin{array}{c}\text { Estimated outturn } \\
\text { by March } 2016 \\
\text { Em p.a. }\end{array}$ \\
\hline Employment and Support Allowance & 500 & 280 & 85 \\
\hline Tax Credits & 300 & 350 & 340 \\
\hline 1 per cent uprating & 290 & 230 & 230 \\
\hline Child Benefit & 225 & 240 & 240 \\
\hline Personal Independence Payments ${ }^{(1)}$ & 165 & 320 & 130 \\
\hline Housing Benefit: LHA & 80 & 80 & 80 \\
\hline Housing Benefit: 'bedroom tax' & 50 & 0 & 0 \\
\hline Non-dependent deductions & 30 & 20 & 20 \\
\hline Benefit cap & 15 & 4 & 3 \\
\hline Total & 1,660 & 1,520 & 1,130 \\
\hline
\end{tabular}

${ }^{(1)}$ Initial and revised estimates are for full impact by March 2018

Source: Sheffield Hallam estimates based on official data

\footnotetext{
${ }^{8}$ See the quarterly briefings on the DWP sanctions statistics produced by David Webster of Glasgow University

${ }^{9}$ Other reforms that have been omitted are the reduction in the qualifying age of the youngest child exempting lone parents from looking for work, which does not reduce payment rates, and the changeover from RPI to CPI for benefits up-rating, introduced in 2011-12, which is a wider accounting reform affecting public sector pensions for example and has in practice been superseded by subsequent caps and freezes for most working-age benefits.

${ }^{10} \mathrm{C}$ Beatty and S Fothergill (2013) op. cit.

${ }^{11} \mathrm{C}$ Beatty and S Fothergill (2015) op. cit.
} 
Overall, the financial loss to claimants in Scotland by March 2016 is estimated to be $£ 1.1 \mathrm{bn}$ a year, which is equivalent to $£ 330$ for every person of working age (16-64). This is only around two-thirds of the $£ 1.6 \mathrm{bn}$ a year loss initially estimated. Part of the difference is illusory however: the changeover from DLA to PIP was never expected to be completed until 2018 and adding in the loss from this source still in the pipeline - by 2018 it is still expected to be $£ 320 \mathrm{~m}$ a year - brings the total loss from the pre-2015 welfare reforms to more than $£ 1.3 b n$ a year. All the other pre-2015 reforms had taken full effect by March 2016.

Furthermore, the outturn loss to claimants in Scotland excludes the impact of the 'bedroom tax', included in the initial figures, which the Scottish Government subsequently offset in full. The intervention of the Scottish Government and Scottish local authorities also averted any reduction in Council Tax Support arising from the cut in funding imposed by the Treasury.

As we noted in our 2015 report, the effect of these interventions was to reduce the financial loss to claimants in Scotland by around £35 a year per adult of working age, equivalent to around 10 per cent of the overall loss that would otherwise have fallen on Scottish claimants by March 2016. The Welsh Government and a number of local authorities in England also avoided passing on reductions in Council Tax Support to claimants but the intervention to head off the impact of the 'bedroom tax' is presently unique to Scotland.

Employment and Support Allowance - the modern-day incapacity benefit - accounts for by far the largest shortfall between initial expectations and the outturn loss to claimants. Three factors are at the root of this:

- $\quad$ The new medical test (the Work Capability Assessment) has reduced numbers by far less than was anticipated, in part because following extensive criticism the test itself has undergone successive revisions. The headline number of incapacity/ESA claimants across Britain as a whole is only down by around 100,000 (to $2.5 \mathrm{~m}$ ) though it could be argued that without the new medical test the numbers would have been higher in the wake of recession.

- Following the medical test a much smaller proportion of ESA claimants have been placed in the Work-Related Activity Group than was originally expected. Again, this is probably attributable in part to revisions to the Work Capability Assessment.

- As a result of the smaller than anticipated numbers in the Work-Related Activity Group, the financial savings to the Treasury arising from the time-limiting of nonmeans tested entitlement have been much less than was expected.

There is nothing unusually Scottish in this lower than expected financial loss arising from incapacity benefit reform. It has happened in all the UK regions. On the other hand, Scotland has for many years had a high incapacity claimant rate so the shortfall in the Treasury's anticipated savings has been proportionately greater in Scotland than in much of southern England, where the incapacity claimant rate is generally lower. 
The losses arising from the cap of 1 per cent a year on the inflation uprating of most working-age benefits have also been lower than initially anticipated. This reflects lower than expected inflation.

Taken as a whole, the divergences between initial expectations and actual losses reflect events and uncertainties in the real world, and in some cases the Treasury's own reassessment of the expected savings, rather than flaws in the methods deployed in this report and its predecessors. The divergences do however underline the point that estimating the impacts of welfare reform is an imprecise science.

\section{The new welfare reforms}

The new welfare reforms impacting on Scotland, announced in the Summer Budget in July 2015 and in the Spending Review and Autumn Statement in November 2015, are:

\section{Universal Credit work allowances ${ }^{12}$}

Reduction in the level of earnings at which Universal Credit is withdrawn as income rises. This reform was originally to have applied to Tax Credits as well but will now only apply to Universal Credit, which is gradually replacing Tax Credits.

\section{Tax Credits}

Reductions in payments and thresholds, notably the removal for new claims of the 'family' element and a limit on the 'child' element to two children for children born after March 2017

\section{Mortgage interest support}

Change from welfare payment to a loan. Loans accrue interest and will be repaid upon the sale of the house or when claimants return to work.

\section{LHA cap in the social rented sector}

Housing Benefit for new tenancies in the social sector limited to the equivalent local private sector rate - the Local Housing Allowance (LHA) determined by age, household composition and location

\section{Housing Benefit: 18-21 year olds}

End of entitlement for new claims to Universal Credit by out-of-work 18-21 year olds, with exemptions for vulnerable groups and those who live independently and have worked continuously for the preceding six months

\section{Employment and Support Allowance}

Reduction in ESA payments to the Jobseeker's Allowance rate for new claimants placed in the Work-Related Activity Group

\footnotetext{
${ }^{12} \mathrm{C}$ Beatty and S Fothergill (2016) op. cit. referred to these as 'Universal Credits tapers and thresholds'. 'Work allowances' is a more accurate terminology.
} 


\section{Benefit cap}

Lower ceiling per household - $£ 23,000$ a year in London, £20,000 elsewhere applying to the total of a wide range of working age benefits

\section{Benefit freeze}

Four-year freeze in the value of most working age benefits, including tax credits and the Local Housing Allowance within Housing Benefit and Universal Credit

Further details of each of these new reforms, including the timing of implementation, are contained in the appendix.

Additionally the Westminster Government announced a new requirement - 'Pay to Stay' for higher income tenants in the social rented sector to pay market rents and a 1 per cent a year reduction in social sector rents for four years, intended to reduce spending on Housing Benefit, which impacts financially on landlords rather than tenants. These measures apply only in England. In Scotland (and in Wales) social sector rents are a devolved matter.

Table 2 shows the resulting financial loss to claimants across Britain as a whole in each financial year up to 2020-21. These are all the Treasury's own estimates, updated in most cases by the revised figures published in the March 2016 Budget ${ }^{13}$. They also include the further loss to claimants that can be expected from the on-going changeover from DLA to PIP initiated prior to 2015.

Table 2: Expected financial loss to claimants from post-2015 welfare reforms, GB, £m

\begin{tabular}{lrrrrr} 
& $\mathbf{2 0 1 6 - 1 7}$ & $\mathbf{2 0 1 7 - 1 8}$ & $\mathbf{2 0 1 8 - 1 9}$ & $\mathbf{2 0 1 9 - 2 0}$ & $\mathbf{2 0 2 0 - 2 1}$ \\
\hline Benefit freeze & 0 & 505 & 1,755 & 3,470 & 3,580 \\
UC work allowances & 120 & 1,225 & 2,225 & 2,850 & 3,190 \\
Tax Credits & 260 & 995 & 1,640 & 2,030 & 2,255 \\
PIP & 810 & 1,680 & 1,680 & 1,680 & 1,680 \\
ESA & 0 & 30 & 180 & 345 & 450 \\
LHA cap in social sector & 0 & 0 & 205 & 310 & 375 \\
Benefit cap (extension) & 70 & 215 & 235 & 295 & 340 \\
Mortgage interest support & -30 & -35 & 265 & 245 & 245 \\
'Pay to stay' & 0 & 275 & 100 & 155 & 140 \\
HB: 18-21 year olds & 0 & 25 & 35 & 40 & 40 \\
\hline Total & $\mathbf{1 , 2 3 0}$ & $\mathbf{4 , 9 1 5}$ & $\mathbf{8 , 3 2 0}$ & $\mathbf{1 1 , 4 2 0}$ & $\mathbf{1 2 , 2 9 5}$ \\
\% of 2020-21 total & $\mathbf{1 0}$ & $\mathbf{4 0}$ & $\mathbf{6 8}$ & $\mathbf{9 3}$ & $\mathbf{1 0 0}$ \\
\hline
\end{tabular}

Source: HM Treasury ${ }^{13}$ Figures for the LHA cap exclude the impact of the revisions affecting supported housing,
announced in September 2016, for which financial data has not yet been published. 
Across Britain as a whole, the Treasury expects the additional loss to claimants to grow to $£ 12.3 b n$ a year by 2020-21. By comparison, by March 2016 the equivalent loss to claimants arising from the pre-2015 reforms, again across Britain as a whole, is estimated to be $£ 14$.9bn a year. In effect, the pace of welfare reform, or more specifically the pace of the financial losses, looks set to slow little if at all. By the spring of 2021, the cumulative loss to claimants arising from all the welfare reforms since 2010 is therefore likely to be some $£ 27 \mathrm{bn}$ a year.

After a slow start in the year to March 2017, when the changeover to PIP accounts for some two-thirds of the financial loss, the Treasury expects the losses attributable to the new reforms to accelerate. The rate of increase then slows again at the end of the decade. Slippage in the timetable for implementing Universal Credit, a persistent problem, may however push some of the financial loss to claimants further away in time.

Over the 2016-21 period as a whole, the Treasury expects to save most from the benefit freeze, the revised work allowances in Universal Credit and reductions in Tax Credits. The changeover from DLA to PIP - still rolling forward from earlier years - also accounts for large sums.

\section{The financial losses in Scotland}

The Treasury does not publish estimates of the expected financial losses in Scotland, or in any other part of Britain. As with the losses arising from the pre-2015 reforms, shown earlier, the figures for Scotland presented below are again estimates based primarily on the Treasury's expected savings across Britain as a whole and local data on the distribution of benefit claimants and spending. The estimates also take account of additional information in the Impact Assessments published by the UK Government.

Table 3 presents our estimates of the financial loss to claimants in Scotland. The figures here are for the expected losses in 2020-21, which is as far ahead as the Treasury's own projections currently extend. By this time most of the new welfare reforms are expected to be fully implemented.

By 2020-21, we estimate that the overall financial loss to claimants in Scotland arising from the new, post- 2015 welfare reforms will be $£ 1,040 \mathrm{~m}$ a year. This compares to a financial loss by March 2016 arising from the pre-2015 reforms of $£ 1,130 \mathrm{~m}$ a year (see Table 1 earlier) and will therefore bring the cumulative loss to claimants in Scotland from all the post2010 welfare reforms up to approaching £2.2bn a year.

As across the UK as a whole, the benefit freeze and the reductions in Universal Credit work allowances are expected to lead to the biggest financial losses in Scotland. The completion of the changeover from DLA to PIP also results in large losses because of the high number of claimants in Scotland. The reductions in Tax Credits are a smaller source of financial loss because Scotland has fewer large families exposed to the new restrictions on eligibility. 


$\begin{array}{cc}\begin{array}{c}\text { Estimated } \\ \text { loss }\end{array} & \begin{array}{c}\text { Number of } \\ \text { households or } \\ \text { individuals }\end{array} \\ \text { Em p.a. } & \text { adversely affected }\end{array}$

Average loss per affected

h'hold/individual

£ p.a.

\begin{tabular}{lrrr}
\hline Benefit freeze & 300 & 700,000 & 450 \\
Universal Credit work allowances & 250 & 240,000 & 1,050 \\
Personal Independence Payments ${ }^{(1)}$ & 190 & 70,000 & 2,600 \\
Tax Credits & 140 & 150,000 & 950 \\
Employment and Support Allowance & 65 & 70,000 & 900 \\
LHA cap in social rented sector & 40 & 55,000 & 750 \\
Benefit cap (extension) & 25 & 11,000 & 2,400 \\
Mortgage interest support & 25 & 17,000 & 1,450 \\
HB: 18-21 year olds & 4 & 1,500 & 2,600 \\
\hline \multirow{2}{*}{ Total } & $\mathbf{1 , 0 4 0}$ & n.a. & n.a. \\
\hline
\end{tabular}

${ }^{(1)}$ Additional post-2015-16 impact of pre-2015 reform
(2) Individuals for PIP, ESA and 18-21s; households for all other benefits

Sources: HM Treasury, Impact Assessments and Sheffield Hallam estimates based on official data

The numbers of people affected by each of the new reforms varies considerably. The benefit freeze affects the largest number because it applies to nearly all working-age benefits, though the loss to each household or individual is relatively small. There is also uncertainty about the final scale of the loss of course, because it depends on inflation rates across the economy some years ahead. By contrast, the average loss to individuals who lose out as a result of the changeover to Personal Independence Payments is likely to be quite large ${ }^{14}$.

The new, extended Benefit Cap is worth singling out. The number of households likely to be affected in Scotland is an apparently modest 11,000 but this compares with just 900 affected by the existing pre-2016 cap, which mainly impacted in London where very high rents pushed significant numbers above the $£ 26,000$ threshold. The new Benefit Cap - 220,000 a year in Scotland - is set to bite harder on larger numbers. The average financial loss per household also looks likely to be substantial - more than $£ 2,000$ a year.

What is worth bearing in mind is that some individuals and households are affected by more than one element of the reform package. It is possible, for example, that a working-age claimant with health problems or disabilities will find that their ESA is reduced and at the same time they lose out though the changeover from DLA to PIP. They may also lose

\footnotetext{
${ }^{14}$ The most recent Treasury estimates of the financial losses associated with the changeover from DLA to PIP were published in 2013 before the changeover was substantially underway.
} 
entitlement Tax Credits if they have children, could be hit by the LHA cap if they live in social housing, and the benefit freeze will affect them too.

By contrast, pensioner households are mostly unaffected by the new welfare reforms, as they were by the pre-2015 reforms. This has been a deliberate policy choice by the Westminster Government, which has targeted welfare reform at men and women of working age with the explicit intention of increasing the financial incentives to find work or, for those already in work, to increase their earnings. The State Pension, in particular, has been exempted from the new reforms and the DLA to PIP changeover only applies to working-age claimants. To lose out financially as a result of the new reforms a pensioner household must be a new social housing tenant affected by the LHA cap, or a recipient of mortgage interest support, or still be able to claim Tax Credits for a child. Small numbers of pensioners fall into these groups.

Because of the overlapping impact of the reforms it is not possible here to provide an estimate of the total number of households or individuals losing out financially, or their average loss. Only the numbers affected by each element of the reforms are included in Table 3 and they should not be summed to create a total. However, the benefit freeze alone means that at least 700,000 will face a loss. Moreover, this is a 'snapshot' at a single point in time. Because the individuals and households that make up the stock of claimants is changing all the time, as people move on and off benefit, the numbers in Scotland who lose out financially at some point can probably be expected to comfortably exceed one million.

The way in which financial losses will be experienced by claimants in Scotland is nevertheless worth noting. The Westminster Government has ensured that relatively few people will actually experience a reduction in the cash value of the benefits they are already receiving. The benefit freeze, for example, reduces the value of payments in real rather than cash terms. Several of the reductions in entitlement also apply only to new claims. These include:

- Reduced Universal Credit work allowances

- Restrictions on 'child' and 'family' elements of Tax Credits

- Lower ESA payment rates

- LHA cap in social sector (new tenancies only)

- End of automatic entitlement to HB for out-of-work 18-21s

So the financial loss from these elements of the reform package will be experienced not as a reduction in an existing payment but as a lower entitlement than would previously have been the case. This is a benefit cut nonetheless.

It is worth bearing in mind too that benefit claimants are not a fixed group of men and women. There is regular turnover, particularly among the claimant unemployed for example. As a result, a person returning to benefit after a gap of a few months is often likely to find that their entitlement has been reduced. Likewise, a change of circumstances that triggers a review of Universal Credit entitlement will mean that the new rules, and lower entitlement, will apply. 
The large savings attributable to the changeover to Personal Independence Payments are different because as the re-testing of existing DLA claimants proceeds the losses will be reductions in existing cash payments. Likewise, the new, lower Benefit Cap will reduce the cash entitlement of existing claimants. It is these reductions in existing payments that are likely to trigger the greatest complaints. If new social sector tenants fail to log that from April 2018 onwards they could face a reduction in Housing Benefit there are likely to be further complaints.

\section{The impact by local authority}

Table 4 shows the estimated financial loss to claimants arising from the new welfare reforms by local authority across Scotland. In this table the authorities are ranked by the loss per adult of working age. This adjusts for the differing population of the authorities and is the best measure of the intensity of the 'hit' in each area. This measure also reflects the almost exclusive focus of the losses on men and women working age.

The biggest impact in absolute terms and on a per capita basis falls on Glasgow, where by 2020-21 the post-2015 welfare reforms are estimated to result in a loss of $£ 167 \mathrm{~m}$ a year, equivalent to $£ 400$ a year for every adult of working age in the city. On per capita basis a number of other older industrial areas are also hit hard. These include West Dunbartonshire, Inverclyde, Dundee, North Lanarkshire and North and East Ayrshire.

By contrast, the financial loss to Edinburgh - an estimated $£ 78 m$ a year, or $£ 230$ per adult of working age - is significantly smaller.

The parts of Scotland that are least affected by the reforms are in North East Scotland, Orkney and Shetland, and two relatively affluent districts (East Renfrewshire and East Dunbartonshire) in the central belt. However, it is worth noting that even in some of these local authorities the absolute losses remain large. Aberdeen residents, for example, can still expect to be $£ 29 \mathrm{~m}$ a year worse off than they would have been if the old benefit rules had continued to apply.

There are no surprises in this geography. In fact, it is remarkably similar to the picture we identified in our 2013 report on the impact of the earlier round of welfare reforms ${ }^{15}$, in which Glasgow was again the worst affected place. In effect, the new welfare reforms reinforce the loss of income in the places worst-hit by the pre-2015 round of reforms. Broadly speaking, the parts of Scotland hit hardest by the new round of reform (such as Glasgow) lose twice as much on a per capita basis as the least affected local authorities, and around 30 per cent more than the average across Scotland as a whole of $£ 300$ a year per adult of working age.

\footnotetext{
${ }^{15}$ C Beatty and S Fothergill (2013) op. cit.
} 
Table 4: Estimated financial loss to claimants from post-2015 welfare reforms by $2020-21$, by local authority

\begin{tabular}{|c|c|c|}
\hline & $\begin{array}{c}\text { Estimated } \\
\text { loss } \\
\text { Em p.a. }\end{array}$ & $\begin{array}{l}\text { Loss per } \\
\text { working age } \\
\text { adult } \\
£ \text { p.a. }\end{array}$ \\
\hline Glasgow & 167 & 400 \\
\hline West Dunbartonshire & 23 & 390 \\
\hline North Ayrshire & 33 & 380 \\
\hline Inverclyde & 19 & 370 \\
\hline Dundee & 36 & 360 \\
\hline North Lanarkshire & 78 & 350 \\
\hline East Ayrshire & 27 & 350 \\
\hline Renfrewshire & 38 & 340 \\
\hline Dumfries and Galloway & 30 & 330 \\
\hline West Lothian & 38 & 330 \\
\hline Clackmannanshire & 11 & 330 \\
\hline Fife & 74 & 320 \\
\hline Midlothian & 17 & 320 \\
\hline South Ayrshire & 22 & 320 \\
\hline South Lanarkshire & 64 & 310 \\
\hline Falkirk & 30 & 290 \\
\hline East Lothian & 18 & 280 \\
\hline Scottish Borders & 19 & 280 \\
\hline Angus & 20 & 270 \\
\hline Highland & 39 & 270 \\
\hline Argyll and Bute & 14 & 270 \\
\hline Eilean Siar & 4 & 260 \\
\hline Perth and Kinross & 24 & 260 \\
\hline Moray & 14 & 240 \\
\hline Stirling & 14 & 230 \\
\hline Edinburgh & 78 & 230 \\
\hline East Renfrewshire & 12 & 220 \\
\hline Orkney Islands & 3 & 210 \\
\hline East Dunbartonshire & 13 & 200 \\
\hline Aberdeen & 29 & 180 \\
\hline Aberdeenshire & 28 & 170 \\
\hline Shetland Islands & 2 & 160 \\
\hline Scotland & 1,040 & 300 \\
\hline
\end{tabular}

Source: Sheffield Hallam estimates based on official data 
It is to be expected that welfare reforms hit hardest in the places where welfare claimants are concentrated, which in turn tend to be the poorest areas with the highest rates of worklessness. To underline this point, Figure 1 shows the relationship between the financial losses arising from the post-2015 welfare reforms (measured in terms of the loss per adult of working age) and the share of the datazones ${ }^{16}$ in each local authority in the most deprived 20 per cent in Scotland (from the Scottish Indices of Deprivation 2016). There is a clear and unambiguous relationship: as a general rule, the more deprived the local authority, the greater the financial hit. What the regression line in Figure 1 tells us is that for every 10 percentage point increase in the share of population in the most deprived 20 per cent of Scottish datazones, the financial loss arising from the new welfare reforms increases by around $£ 40$ a year per adult of working age.

Figure 1: Relationship between deprivation and estimated financial loss by 2020-21 arising from post-2015 welfare reforms, by local authority



Sources: Sheffield Hallam estimates and Scottish Indices of Deprivation 2016

${ }^{16}$ Datazones are small geographical units with between 500 and 1,000 residents. 


\section{Comparisons with the rest of Britain}

Table 5 compares the financial loss in Scotland with the rest of Britain. What is clear here is that although the anticipated financial loss in Scotland is large - a little over £1bn a year by 2020-21 - it is in fact quite close to the average for Great Britain as a whole - the Scottish loss of $£ 300$ a year per adult of working age compares to the GB average of $£ 310$ a year.

Table 5: Estimated financial loss to claimants by 2020-21 arising from post-2015 welfare reforms, by region and country

\begin{tabular}{lcc}
\hline & $\begin{array}{c}\text { Estimated } \\
\text { loss } \\
\text { Em p.a. }\end{array}$ & $\begin{array}{c}\text { Loss per } \\
\text { working age adult } \\
\text { £ p.a. }\end{array}$ \\
\hline North West & 1,630 & 360 \\
North East & 590 & 360 \\
Wales & 680 & 360 \\
West Midlands & 1,250 & 350 \\
Yorkshire and the Humber & 1,170 & 350 \\
East Midlands & 920 & 320 \\
London & 1,770 & 300 \\
Scotland & 1,040 & 300 \\
South West & 930 & 280 \\
East & 990 & 270 \\
South East & 1,320 & 240 \\
\hline Great Britain & $\mathbf{1 2 , 2 9 5}$ & 310 \\
\hline
\end{tabular}

Source: Sheffield Hallam estimates based on official data

A number of other parts of Britain are in fact hit harder. Wales and the three regions of northern England all come above Scotland in this particular ranking. So do the East and West Midlands. That Scotland loses less, per adult of working age, than some of the English regions is partly because the Westminster Government's new 'Pay to Stay' arrangements for higher-income social sector tenants do not apply in Scotland. But Scotland's position in the rankings also reflects the fact that as well as having clearly deprived areas, notably in the West, it also includes a number of prosperous sub-regions - the Edinburgh and Aberdeen areas in particular. These dilute the average financial loss across Scotland as a whole.

On the other hand, the remaining regions of southern and eastern England outside London, generally regarded as covering some of the most prosperous parts of the UK, are on a per capita basis all hit less hard than Scotland. 


\section{Will the loss of income be offset?}

Welfare reform is of course only one of several things happening simultaneously. It is not within the scope of the present report to cover all these in detail but the extent to which the financial losses might be offset, at least for some people, deserves comment.

The increase in personal tax allowances is one offsetting factor. Over the 2010-15 period the Coalition government increased the personal allowance for Income Tax by more than the rate of inflation. In its 2015 Summer Budget, the Conservative government pledged to further increase the allowance from $£ 10,600$ in $2015-16$ to $£ 12,500$ by 2020-21.

Two points are worth bearing in mind about the impact of changes in personal allowances. The first is that only a proportion of benefit claimants actually pay Income Tax. Those in fulltime employment will typically do so but there are many others - especially women - in lowpaid part-time employment who have an income below tax thresholds. Those on out-of-work benefits will generally be in this position too. The other point is the scale of the tax changes. Raising the personal allowance by $£ 1,900$ a year between 2015-16 and 2020-21 is worth $£ 380$ a year to the individual taxpayer (at a 20 per cent tax rate), but around half of this increase might have been expected anyway if the allowance had been uprated in line with inflation ${ }^{17}$.

The introduction of the National Living Wage is a second offsetting factor. From April 2016 this is $£ 7.20$ an hour for workers aged 25 or more - an increase of 70p compared to the previous minimum wage - and it is the government's aspiration to raise the National Living Wage to over £9 an hour by 2020. In the short-run the government expects this to boost the earnings of $2.7 \mathrm{~m}$ low wage workers, with knock-on effects further up the wage distribution for perhaps a further $3.25 \mathrm{~m}^{18}$.

Whilst the introduction of the National Living Wage boosts earnings of the low paid, revised work allowances within Universal Credit increase the withdrawal of financial support from many of the same people. On balance, many of the low paid are likely to find that they are little if at all better off. Illustrative figures in Summer Budget 2015 suggest that the combined effect of welfare reform, personal tax changes and the National Living Wage will be to generate a range of both positive and negative changes in real income by 2020-21, depending on household structure and hours worked (if any).

Discretionary Housing Payments are a potential third offsetting factor. These are payments administered by local authorities to provide additional support to help meet housing costs for those in receipt of Housing Benefit or the housing component of Universal Credit.

Two points need to be noted about Discretionary Housing Payments. First, the Westminster Government's financial allocation of $£ 800 \mathrm{~m}$, in the Summer Budget 2015, is for a five year period so on an annual basis it averages only $£ 160 \mathrm{~m}$, and Scotland's proportional share is only around £15m a year. Second, the Scottish Government is already committed to

\footnotetext{
${ }^{17}$ Office for Budget Responsibility inflation forecast in Summer Budget 2015

${ }^{18}$ Source: HM Treasury (2015) Summer Budget 2015, op. cit.
} 
spending the whole of this sum - and substantially more - to continuing to offset the 'bedroom tax'.

A fourth offsetting factor is the extension of support for childcare. From early 2017, the Westminster Government is introducing tax-free childcare up to the value of $£ 2,000$ per child. In England, the Westminster Government is also funding additional free childcare for working parents of 3 and 4 year olds from September 2017. In Scotland, the same entitlement is planned to increase from 15 to 30 hours a week by the end of the current Parliament and will in addition cover around a quarter of 2 year olds. The increase is estimated to be worth up to $£ 2,500$ a year per child ${ }^{19}$. The net cost to the Exchequer of the recently-announced changes, including restrictions on the entitlement of the highest earners, is estimated to be $£ 585 \mathrm{~m}$ a year in $2020-21^{20}$.

For some households these reductions in childcare costs are substantial and they will go a long way towards offsetting, perhaps even entirely, the loss of income arising from the welfare reform package. On the other hand it is worth bearing in mind that the financial loss to households with dependent children arising from welfare reform extends far beyond just those with 3 and 4 year olds. Also, at least some of the financial benefit of the reduction in childcare costs will feed through to middle and upper-income households in work who do not draw on the benefit system to any significant extent and are largely unaffected by the welfare reforms.

Taken as a whole, all these parallel changes in taxation, wages and entitlement go some way to offsetting the financial losses arising from welfare reform. However, it is clear that the winners and the losers are unlikely to be the same people. It also looks unlikely that the full financial loss will be offset in this way.

\section{Will more people find employment?}

Westminster ministers take the view that the welfare reforms increase the financial incentive to take up employment and because more people will look for work more people will find work. In this view, employment will be higher and the loss of benefit income will be offset in whole or in part by an increase in earnings.

What is true is that since 2012, at around the time that many of the first round of welfare reforms began to bite, UK employment has grown strongly - more strongly indeed than normal given the modest growth in output. It would be wrong, however, to assume that welfare reform has been the trigger. Other factors almost certainly lie at the root of the upturn - the revival in household borrowing, especially around the housing market, the recovery of the world economy and exceptionally low interest rates. The reforms to out-ofwork benefits do however increase the financial incentive to work.

On the other hand, even before the reforms began most out-of-work claimants would have been financially better off in employment. Financial disincentives only came into play for

\footnotetext{
${ }^{19}$ Source: Spending Review and Autumn Statement 2015

${ }^{20}$ Sources: Summer Budget 2015 and Spending Review and Autumn Statement 2015
} 
relatively small numbers at specific cut-off points in the system. Moreover, some reforms to in-work benefits - the changes to Universal Credit work allowances for example - have the opposite effect, making work less financially rewarding, and many in employment may find it difficult to increase their working hours to offset the loss of income.

For claimants of Employment and Support Allowance, who are by far the largest group on out-of-work benefits in Scotland and elsewhere, it is also questionable whether increasing the financial incentive to work really addresses their obstacles to employment. For some ESA claimants health problems or disabilities pose a formidable barrier, and even for those closer to the labour market there are generally unresolved health issues. Additionally, ESA claimants are disproportionately concentrated in the weaker local labour markets where employers are generally able to recruit plenty of fit and healthy workers.

Central to the view that employment will rise in the wake of the welfare reforms is the assumption that extra labour supply leads to extra labour demand from employers. Whether labour markets really do work in this way is deeply questionable. There are times and places where a shortage of labour can bottle-up economic growth but particularly in the places where the local economy is weak - which is where so many out-of-work claimants are concentrated - the likelihood of an increase in labour supply triggering an increase in employment is low. Some individuals will undoubtedly find work to compensate for the loss of benefit income but whether the overall level of employment will be any higher as a result is questionable. More often than not, the claimants finding work will simply fill vacancies that would have gone to other jobseekers, thereby transferring unemployment from one person to another.

Our pilot study in Scotland ${ }^{21}$ found that the unemployment (JSA) claimant rate has fallen fastest in the local authorities where the financial losses from welfare reform have been largest. Closer examination, however, showed that the same areas - which were the places that started with the highest unemployment - also experienced the biggest reductions in unemployment in previous economic upturns, long before the implementation of welfare reform.

\section{Concluding remarks}

Important elements of the welfare system are being devolved to Scotland and this will no doubt command attention in the Scottish Parliament. In total the devolved benefits accounted for $£ 3.1 \mathrm{bn}$ spending in Scotland in 2014-15, compared to £15bn spent in Scotland via the benefits reserved to Westminster, split fairly evenly between working-age and retirement benefits ${ }^{22}$.

However, the devolution of welfare powers should not obscure the continuing role of that Westminster plays in determining benefit spending in Scotland. In particular, it is important to keep in mind the major impact on Scotland of the welfare reforms initiated by the

\footnotetext{
${ }^{21} \mathrm{C}$ Beatty, S Fothergill and D Houston (2015) op. cit.

${ }^{22} \mathrm{~K}$ Wane, K Berry, C Kidner and N Georghiou (2016) New Social Security Powers, SPICe briefing 16/45, Scottish Parliament, Edinburgh
} 
Westminster Government since the 2015 general election. From the claimant's perspective, what matters is not who controls the levers but how much they will receive, and for many this is set to be reduced.

In this report we have estimated that the post-2015 welfare reforms will result in a financial loss to claimants in Scotland of just over £1bn a year by 2020-21. This comes on top of an earlier financial loss of $£ 1$.1bn a year by March 2016 arising from the welfare reforms implemented by the Westminster Government between 2010 and 2015. Even the devolved benefits do not escape unscathed: by the time that responsibility for Personal Independence Payments is devolved in 2018, we estimate that a further $£ 190 \mathrm{~m}$ a year will have been taken from claimants in Scotland as a result of the on-going replacement of DLA by PIP. As a result, a smaller budget line will eventually be handed over.

Welfare claimants in Scotland have lost large sums already, and are set to lose further large sums. The devolution of welfare powers will not in itself alter this stark reality. 


\section{APPENDIX 2: Details of statistical sources and methods}

\section{PERSONAL INDEPENDENCE PAYMENTS}

Payments intended to help offset the additional financial costs faced by individuals of all ages with disabilities, including those both in and out of work

\section{Nature of reform}

- Phased replacement of Disability Living Allowance (DLA) for working-age claimants by Personal Independence Payments (PIP), from 2013-14

- Introduction of more stringent medical test and regular re-testing

- Reduction in number of payment categories

\section{Total estimated loss}

$£ 2,870 \mathrm{~m}$ a year by $2017-18$, of which $£ 1,680 \mathrm{~m}$ a year arises after 2015-16

(Source: HM Treasury revised estimate, Budget 2013)

\section{Methods and data sources}

- DWP anticipate a reduction in the national caseload of working age of 600,000 (see National Audit Office (2014) Personal Independence Payment: early progress, NAO, London), up from an original DWP estimate of 450,000. Additionally, 510,000 claimants in receipt of PIP instead of DLA are anticipated to experience a reduction in payment.

- Numbers allocated on the basis of stock of working age DLA claimants in each local authority in February 2012 (Source: DWP).

- Financial loss allocated to each local authority in GB on basis of reduction in claimant numbers

\section{UNIVERSAL CREDIT WORK ALLOWANCES}

Benefit withdrawal as income of Universal Credit (UC) claimant rises

\section{Nature of reforms}

- Reduction in the level of earnings at which UC awards start to be withdrawn, from April 2016

Total estimated loss

$£ 3,190 \mathrm{~m}$ a year (net) by $2020-21$

(Source: HM Treasury Budget 2016)

\section{Methods and data sources}

- Overall loss allocated on the basis of the total number of families in work in receipt of CTC or WTC in December 2015, by local authority across GB (Source: HMRC Child and Working Tax Credits Statistics: geographical analysis)

- All families in work in receipt of CTC or WTC affected by the changes 


\section{TAX CREDITS (new reforms)}

Payments through the tax system to lower and middle income households, initially as Child Tax Credit and Working Tax Credit and eventually Universal Credit

\section{Nature of reforms}

- Limiting of child element to two children for new births in tax credits and new UC claims, from April 2017 ( $£ 1,585 \mathrm{~m}$ a year by 2020-21)

- Removal of family element in tax credits and UC, and the family premium in Housing Benefit, for new claims, from April 2017 ( $£ 645 \mathrm{~m}$ a year by 2020-21)

- Reduction in income rise disregard in tax credits, from April 2016 ( $£ 55 \mathrm{~m}$ a year by 2020-21)

- Uprated minimum income floor in UC for self-employed from 2016-17 ( $£ 185 \mathrm{~m}$ a year by 2020-21)

- Revised UC delivery schedule ( $215 \mathrm{~m}$ extra spending in 2020-21 but net saving in earlier years)

\section{Total estimated loss}

$£ 2,255 \mathrm{~m}$ a year (net) by 2020-21

(Sources: HM Treasury Spending Review and Autumn Statement 2015 and Budget 2016)

\section{Methods and data sources}

- Estimated numbers of households affected by child element $(640,000)$ from DWP Impact Assessment: Tax Credits and Universal Credit, changes to Child Element and Family Element

- 30 per cent of other tax credit claimants in December 2015 (Source: HMRC) assumed to be affected by one or more of the other changes. Family element is expected to affect 1,180,000 households (Source: DWP Impact Assessment above) but there is overlap with those affected by the child element.

- 70 per cent of financial loss (more than two children element) allocated on basis of number of families in receipt of Child Tax Credit multiplied by an index of the share of households with three or more dependent children in each local authority relative to the GB average in 2011 (Source: Census of Population).

- 30 per cent of financial loss (remaining measures) allocated on basis of numbers in receipt of tax credits in December 2015 (Source: HMRC Child and Working Tax Credits: geographical analysis)

- Total numbers affected in each local authority across GB allocated in proportion to financial losses

\section{MORTGAGE INTEREST SUPPORT}

Assistance with mortgage payments for out-of-work claimant

\section{Nature of the reform}

- Change from welfare payment to loan, from April 2016

\section{Total estimated loss}

$£ 245 \mathrm{~m}$ a year by $2020-21$

(Source: HM Treasury Budget 2016) 


\section{Methods and data sources}

- 170,000 households affected (Source: DWP Welfare Reform and Work Bill: impact assessment for converting support for mortgage interest from a benefit into a loan).

- Number of households affected and financial loss allocated to local authorities across GB in proportion to working-age benefit claimant numbers in each authority in May 2015 (Source: DWP) multiplied by an index of the share of households in owner-occupied housing relative to the GB average in 2011 (Source: Census of Population)

\section{LHA CAP IN SOCIAL RENTED SECTOR}

Support with housing costs for social sector tenants

\section{Nature of the reform}

- Housing Benefit in the social sector limited to the equivalent private sector rate for tenancies signed after 1 April 2016, with entitlement changing from 1 April 2018

\section{Total estimated loss}

$£ 375 \mathrm{~m}$ a year by $2020-21$

(Source: HM Treasury Budget 2016)

\section{Methods and data sources}

- Financial loss arising from LHA cap allocated in proportion to number of households in social housing claiming Housing Benefit in each local authority across GB in August 2015 multiplied by the ratio between the value of the average Housing Benefit claims in the social and private rented sectors in August 2015 (Sources: DWP)

- In absence of published government estimates, the number of households affected assumed to be 500,000 (given the Treasury's anticipated financial saving, this equates to an average loss of $£ 15$ per week per household). Numbers allocated in proportion to the financial losses.

\section{HOUSING BENEIT: 18-21 YEAR OLDS}

Support with housing costs for young people

\section{Nature of the reform}

- End of automatic Housing Benefit entitlement for out-of-work 18-21 year olds, from April 2017

\section{Total estimated loss}

$£ 40 \mathrm{~m}$ a year by $2020-21$

(Source: HM Treasury Budget 2016)

\section{Methods and data sources}

- In absence of government estimates, but in line with anticipated financial saving, numbers affected assumed to be 15,000 , equating to an average loss of roughly $£ 50$ a week

- Number and financial losses allocated in proportion to the out-of-work claimant rate among under25s in each local authority across GB in May 2015 (Source: DWP) 


\section{EMPLOYMENT AND SUPPORT ALLOWANCE (new reforms)}

Out-of-work payments to men and women of working age with health problems or disabilities

\section{Nature of the reform}

- ESA in Work-Related Activity Group reduced to JSA rate for new claims

Total estimated loss

$£ 450 \mathrm{~m}$ a year by $2020-21$

(Source: HM Treasury Budget 2016)

\section{Methods and data sources}

- Numbers affected $(500,000)$ from DWP Impact Assessment: remove the ESA Work-Related Activity Component and the UC Limited Capability for Work Element for new claims

- Numbers affected and financial losses allocated in proportion to the numbers claiming ESA in the WRAG group in each local authority across GB in May 2015 (Source: DWP)

\section{BENEFIT CAP (extension)}

Ceiling on total payments to out-of-work households applying to sum of wide range of working age benefits

\section{Nature of reform}

- New, lower ceiling set at $£ 23,000$ a year in London and $£ 20,000$ elsewhere, from 2016-17

Total estimated loss

$£ 340 \mathrm{~m}$ a year by $2020-21$

(Source: HM Treasury Budget 2016)

\section{Methods and data sources}

- Households already capped in London $(10,000)$ and in the rest of Britain $(13,000)$ lose $£ 3,000$ a year and $£ 6,000$ a year respectively. Numbers are averages for March-August 2015 (Source DWP). Households already capped therefore lose $£ 108 \mathrm{~m}$ a year.

- Remaining financial loss to newly capped households ( $£ 232 \mathrm{~m}$ a year) expected to average $£ 39$ per week, or £2,000 a year. (Source: DWP Welfare Reform and Work Bill: impact assessment for the benefit cap). This equates to 115,000 newly-capped households.

- 24 per cent of all households affected by the new cap $(140,000)$ expected to be in London and 76 per cent elsewhere (Source: DWP Welfare Reform and Work Bill: impact assessment for the benefit cap). Implies 23,000 newly-capped households in London and 93,000 elsewhere.

- Financial loss to newly-capped households in London limited to $£ 3,000$ a year and assumed to be an average of $£ 1,300$ a year ( $£ 30 \mathrm{~m}$ in total)

- Loss of remaining $£ 202 \mathrm{~m}$ a year to 93,000 newly capped households outside London therefore estimated to average $£ 2,200$ a year 
- Number of newly capped households affected in London and in the rest of GB allocated to each local authority: one-third in proportion to number on out-of-work benefits in May 2015 (Source: DWP); one-third in proportion to the ratio between the local share of households with 3 or more children and the GB average in 2011 (Source: Census of Population); and one-third in proportion to the ratio between the local value of Housing Benefit awards and the GB average in August 2015 (Source: DWP)

\section{BENEFIT FREEZE}

Below-inflation uprating of benefits

\section{Nature of reform}

- Freeze in value of most working-age benefits for four years from 2016-17

\section{Total estimated loss}

$£ 3,580 \mathrm{~m}$ a year by $2020-21$

(Source: HM Treasury Budget 2016)

\section{Methods and data sources}

- Total loss divided 40:60 between DWP-administrated benefits and HMRC-administrated benefits (Child Benefit, CTC, WTC), reflecting the current split of overall expenditure on relevant benefits (Sources: DWP and HMRC)

- HMRC benefits loss allocated on basis of total number of families in receipt of CTC or WTC by local authority across GB in December 2015, (Source: HMRC Child and Working Tax Credits: geographical analysis)

- DWP benefits loss divided 70:30 between working age benefits and Housing Benefit, reflecting the current split of overall expenditure on relevant benefits (Source: DWP)

- DWP working age benefits loss allocated on basis of out-of-work working age benefit numbers in May 2015, by local authority across GB (Source: DWP)

- Housing Benefit loss allocated on basis of number claimants and average award in the private rented sector, by local authority across GB (Source: DWP)

- Estimated 30 per cent of all households affected (Source: DWP Welfare Reform and Work Bill: impact assessment of the benefit rate freeze). Allocated to local authorities across GB in proportion to the sum of the numbers in receipt of Child Benefit in December 2015 (Source: HMRC) and out-of-work working-age benefits in May 2015 (Source: DWP). 


\section{Sheffield Hallam University}

The Impact on Scotland of the New Welfare Reforms

BEATTY, Christina <http://orcid.org/0000-0003-0943-9979> and FOTHERGILL, Stephen $<$ http://orcid.org/0000-0002-4201-0640>

Available from the Sheffield Hallam University Research Archive (SHURA) at:

http://shura.shu.ac.uk/15885/

\section{Copyright and re-use policy}

Please visit http://shura.shu.ac.uk/15885/ and http://shura.shu.ac.uk/information.html for further details about copyright and re-use permissions. 